\title{
Mediastinal cyst: a rare cause of acute respiratory distress in an adult
}

\author{
Zoe Elizabeth Barber, ${ }^{1}$ Thomas David Dobbs, ${ }^{2}$ Mitra Shahidi ${ }^{1}$ \\ ${ }^{1}$ Stoke Mandeville Hospital, Aylesbury, UK \\ 2John Radcliffe Hospital, Oxford, UK \\ Correspondence to Zoe Elizabeth Barber, zbarber@doctors.net.uk
}

\section{DESCRIPTION}

A 57-year-old woman attended the accident and emergency department in acute respiratory distress with a background of a longstanding retrosternal 'ache'. She had previously presented to the accident and emergency department with a similar history, which responded to nebulised salbutamol, and had therefore previously been given a diagnosis of asthma. On this occasion, she did not respond to asthma treatment and required ventilatory support in the intensive care unit.

A chest radiograph on admission showed an abnormal mediastinal contour that, in retrospect, had been present on previous chest radiographs. She subsequently underwent CT and MRI of her chest. The MRI showed a $9.4 \mathrm{~cm} \times 7.3 \mathrm{~cm} \times 10 \mathrm{~cm}$ central mediastinal cyst compressing both main bronchi (figure 1). She underwent bronchoscopic drainage of the cyst acutely, which was clinically and bronchoscopically successful, and definitive surgical excision via median sternotomy 1 month later. Histology confirmed a foregut duplication cyst. A follow-up CT at 1 year after excision showed no recurrence.

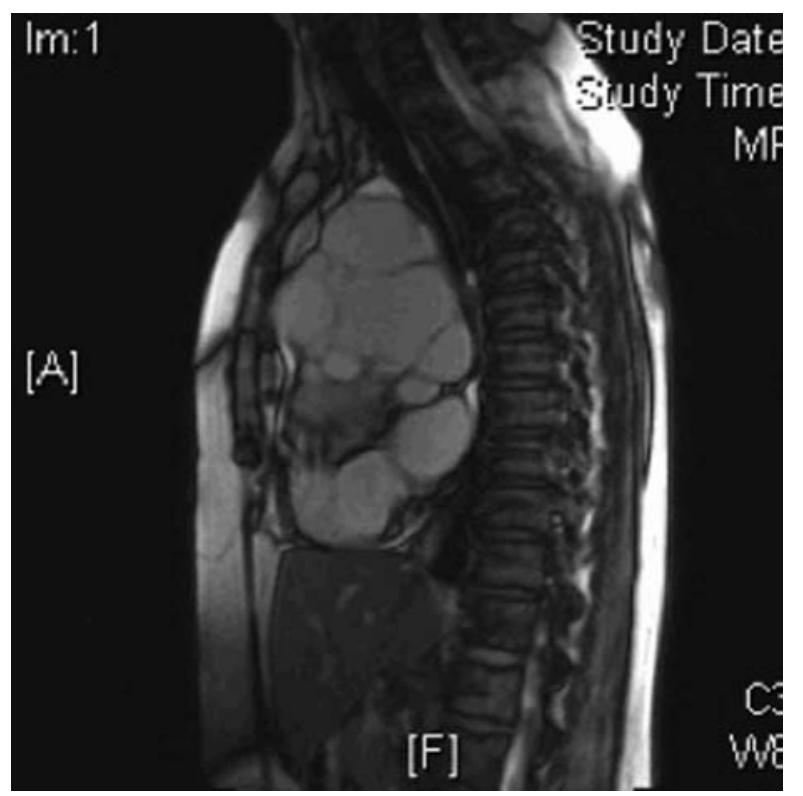

Figure 1 Sagittal MRI showing a large, multiloculated mediastinal cyst.
Foregut duplication cysts are seen in children but rarely in adults. ${ }^{12}$ Complications include respiratory distress, haemoptysis and acute rupture. ${ }^{3}$ Surgical excision offers definitive management as bronchoscopic drainage, though successful at managing acute airway obstruction by the cyst, leaves the cyst able to refill.

\section{Learning points}

- Mediastinal cysts are a rare, but important, cause of acute respiratory distress.

- If a patient fails to respond to therapy based on a previous diagnosis or previous imaging, it is important to reconsider the initial diagnosis and review all previous investigations to consider alternative diagnoses.

Competing interests None.

Patient consent Obtained.

\section{REFERENCES}

1. Holcomb GW, Gheissari A, O'Neill JA. Surgical management of alimentary tract duplications. Ann Surg 1989;209:167-74.

2. Fitz RH. Persistent omphalomesenteric remains: their importance in the causation of intertinal duplication, cyst formation and obstruction. Am J Med Sci 1884;88:30-57.

3. Burgher DP, Carachi R, Beattie TJ. Foregut duplication cyst presenting as neonatal respiratory distress and haemoptysis. Thorax 2004;49:287-8. 


\section{BMJ Case Reports}

This pdf has been created automatically from the final edited text and images.

Copyright 2012 BMJ Publishing Group. All rights reserved. For permission to reuse any of this content visit http://group.bmj.com/group/rights-licensing/permissions.

BMJ Case Report Fellows may re-use this article for personal use and teaching without any further permission.

Please cite this article as follows (you will need to access the article online to obtain the date of publication).

Barber ZE, Dobbs TD, Shahidi M. Mediastinal cyst: a rare cause of acute respiratory distress in an adult. BMJ Case Reports 2012;10.1136/bcr-2012-006276, Published XXX

Become a Fellow of BMJ Case Reports today and you can:

- Submit as many cases as you like

- Enjoy fast sympathetic peer review and rapid publication of accepted articles

- Access all the published articles

- Re-use any of the published material for personal use and teaching without further permission

For information on Institutional Fellowships contact consortiasales@bmjgroup.com

Visit casereports.bmj.com for more articles like this and to become a Fellow 